Egyptian Journal of Aquatic Biology \& Fisheries

Zoology Department, Faculty of Science,

Ain Shams University, Cairo, Egypt.

ISSN $1110-6131$

Vol. 23(2): $43-54$ (2019)

www.ejabf.journals.ekb.eg

\title{
Some Biological Aspect and Gonads Histology of Sepia savignyi (Blainville, 1827), in the Gulf of Suez, Egypt.
}

\author{
Amal M. Amin ${ }^{1}$, Alaa M. M. Elhalfawy ${ }^{2}$, Hafz M. M. Khouraiba ${ }^{3}$ and \\ Mervat A. M. Ali ${ }^{3}$ \\ 1- Fisheries Department, National Institute of Oceanography and Fisheries, Suez, \\ Egypt \\ 2- General Organization for Export and Import, Cairo, Egypt. \\ 3- Department of Animal Production and Fish Resources, Faculty of Agriculture, \\ Suez Canal University, Egypt. \\ *Corresponding author: aminamal30@yahoo.com
}

\section{ARTICLE INFO \\ Article History: \\ Received: Feb. 20, 2019 \\ Accepted:March 25, 2019 \\ Online: May 20, 2019}

\section{Keywords:}

Sepia savignyi

Oogenesis

Spermatogenesis

Gonadosomatic index

Gulf of Suez

\begin{abstract}
This work is the first histological description of gonad maturation of Sepia savignyi and the beginning of future research on its basic biology. A total of 452 samples, ranged in dorsal mantle length from 3.9 to $29 \mathrm{~cm}$ with average $16.35 \pm 1.50$ and total weight ranged from 19 to $1826.8 \mathrm{gm}$, with average $606.79 \pm 110.7$, of which 269 , female and 183 male were examined between September 2014 to May 2015 obtained from the Gulf of Suez, Egypt. The size at first sexual maturity $\left(\mathrm{DML}_{50}\right)$ was 11.9 and $8.4 \mathrm{~cm}$ for female and male, respectively. The Gonadosomatic indices show that the females and males have two peaks in the year-round spawning period the first is in December $(4.1 \%)$ and $(2.4 \%)$ and the second is in April (3.5\%) and $(2.2 \%)$ for female and male, respectively. Five stages of gonad maturation were established for the female and male, namely immature (I), maturing (II), mature (III), spawning (IV) and spent (V) based on macroscopic examination. Histological examination showed that each ovary and testis had various stages of oocyte and spermatocytes. Oogenesis of oocyte demonstrated seven stages of maturity in females as oogonia, early primary oocyte, late primary oocyte, previtellogenic oocyte, vitellogenic Oocyte, advanced vitellogenic oocyte and ripe oocytes. Spermatogenesis of testes divided into spermatogonia, primary and secondary spermatocytes, spermatid and spermatozoa.
\end{abstract}

\section{INTRODUCTION}

Cuttlefish are marine animals belong to Class Cephalopoda. They are widespread throughout worldwide oceans inhabiting the warm, tropical shallows to the cold depths. In the Gulf of Suez, cephalopod fishery is economically very important, due to its high commercial values in the national and international markets. The cuttlefish's catch in the Gulf of Suez composed of four species; Sepia savignyi, S. pharaonis, S. dollfusi, and S. trygonina but $S$. savignyi was the most abundant species.

Knowledge of reproduction is important in solving some fishery management questions such as the determination of spawning stock. Moreover, a correct identification of mature individuals in the population is thus a crucial step for a 
precise estimation of spawning stock biomass, and finally for assessing the status of the stock and establishing harvest level. Although, there are some data, regarding reproductive biology of cuttlefish all over the world (Önsoy and Salman, 2005; Ghazvineh et al., 2012; Dursun et al., 2013; and Salman, 2015), there is no any histological studies on Sepia savignyi in the Gulf of Suez. Few studies have contrasted the morphological maturity scale with the histological analysis in other cephalopod species such as squid loligo vulgaris Sauer and Lipinski. (1990), Sepia. dollfusi Gabr (1998), Octopus vulgaris Gonçalves et al., (2002) and Octopus vulgaris Cuccu et al., (2013).

This work is the first study on the histological description of gonad maturation of Sepia savignyi from the Gulf of Suez, Egypt. Which the beginning of future research on its basic biology. It is intended to estimate the size at first maturity of Sepia savignyi, which used as a basis of the minimum legal size determination. Also, it assesses the reproductive biology of Sepia savignyi based on the morphological and histological description of the gonadal development and determination of the spawning season during the investigated period.

\section{MATERIALS AND METHODS}

Samples of Sepia savignyi (269 females and 183 males) collected from the Suez Gulf (El- Ataka port) during the fishing season from September 2014 to May 2015. In the laboratory, the dorsal mantle lengths (DML) were measured within $0.1 \mathrm{~cm}$, total body weights (TW) within $0.01 \mathrm{~g}$, and gonad weights (GW) within $0.01 \mathrm{~g}$. Specimens were dissected to determine sex and maturity stage.

Length at first sexual maturity ( $\left.\mathrm{L}_{\mathbf{5 0} \%}\right)$

The length at which $50 \%$ of Sepia reaches their sexual maturity was estimated by fitting the percentage maturity against mid-lengths (king, 1995).

\section{Gonadosomatic indices (GSI)}

Gonado-somatic index (GSI) was determined by using the following equation:

\section{Gonad Histology}

$$
\text { GSI }=(\text { Weight of gonad / Body weight }) \times 100
$$

Small pieces of gonad were fixed for $48 \mathrm{~h}$ in Bouin's solution and then transferred to $70 \%$ ethyl alcohol for preservation. Clearing and paraffin embedding were performed using standard histological techniques; sections were cut at $7 \mu \mathrm{m}$ thickness by using automatic microtome LKB and stained by Hematoxylin and eosin Bancroft and Stevens (1996). The tissues were investigated using a Leica microscope, equipped with a digital camera. Maturity stages for each sex were determined by using Gabr et al. (1998) scale with some modifications.

\section{RESULTS AND DISCUSSION}

\section{Length at first sexual maturity}

Size at first sexual maturity $\left(1_{50}\right)$ has been considered as a reference point of minimum legal size to prevent stock destruction. It has been employed by many fisheries managers as a management measure of fish stock. The smallest mature female was $7.5 \mathrm{~cm}$ in ML and the lengths from 3.9 to $6.5 \mathrm{~cm}$ are immature. The size at maturity $\left(\mathrm{ML}_{50}\right)$ was $11.9 \mathrm{~cm}$ for females. Maturity increased with increased length and the dominant mature female showed from lengths 7.5 to $29.5 \mathrm{~cm}$. The percent of maturity in males increase in length where lengths 4.5 and $5.5 \mathrm{~cm}$ were completely immature. The smallest mature male was $6.5 \mathrm{~cm}$ and the $\mathrm{ML}_{50}$ was $8.4 \mathrm{~cm}$ for ML 
(Fig. 1) .Throughout the species range, males of sepia species reach maturation at smaller sizes than females Gabr et al, (1998) which found that the size at maturity for $S$. pharaonis was $61 \mathrm{~mm}$,ML for males and $122 \mathrm{~mm}$, ML for females, while for $S$. dollfusi was recorded in 7.5 and $8.4 \mathrm{~cm}$ for male and female respectively Önsoy and Salman (2005). recorded( $\left.\mathrm{ML}_{50}\right)$ of $S$. officinalis in $13 \mathrm{~cm}$ ML for females and $9 \mathrm{~cm}$ for males Difference in values in size at first sexual maturity between species might occur due to temperature according to different environments. Actually, common cuttlefish, which stay in warm waters, are maturing earlier than those that are in cold waters, according to Boletzky (1988).

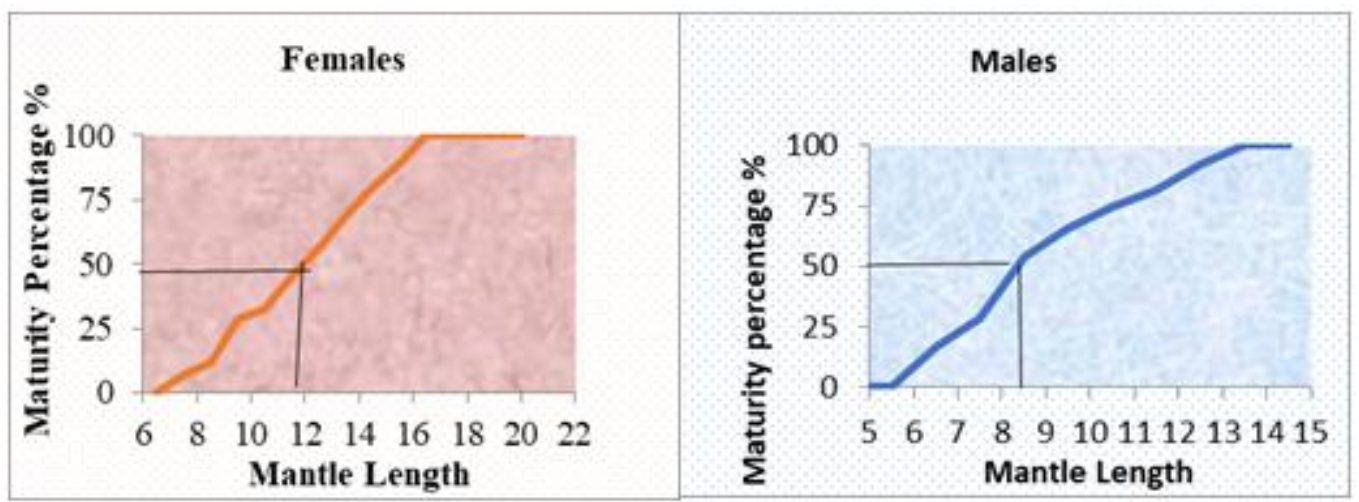

Fig. 1: Female and male distribution of $50 \%$ of the population $\left(\mathrm{ML}_{50}\right)$ at the size of maturity of $S$. savignyi obtained from the Gulf of Suez during the fishing season from

Our results are practically coincident with Mehanna and El-Gammal (2010) from the Gulf of Suez $\left(\operatorname{MLm}_{50} 9.51 \mathrm{~cm}\right.$ ML male; female $10.22 \mathrm{~cm}, \mathrm{ML}$ of $S$. savignyi) El-Sherbeny ( 2009 )from the Gulf of Suez recorded $\mathrm{L}_{50}$ for the sexes combined $13.7 \mathrm{~cm} \mathrm{ML}$, for $S$. savignyi. Our result would not conform to this because sex must be separate.

\section{Gonadosomatic index (GSI)}

GSI is important for deciding the reproductive cycle of $S$. savignyi in the Gulf of Suez. It implies that the females and males have two peaks in the year-round spawning period where firstly is in April (3.5\%) and (2.2) and the second is in December (4.1\%) and (2.4) for female and male, respectively. (Fig. 2)

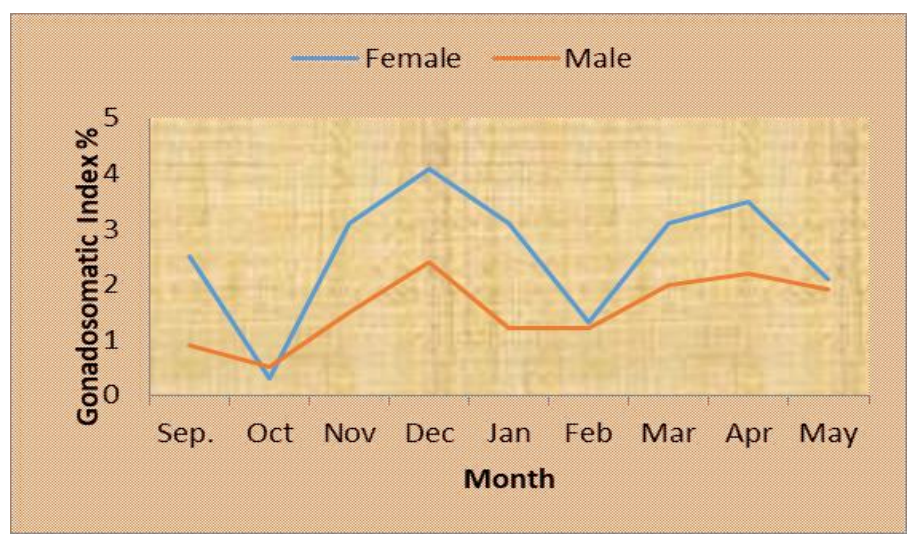

Fig. 2: Monthly female and male gonadosomatic index values of S. savignyi obtained from the Gulf of Suez during the fishing season from September 2014 to May 2015.

Various authors confirmed that there are two peaks of GSI in numerous Sepia species such as. Gabr et al ., (1998) in Suez canal observed that $S$. dollfusi have two beaks in January-April also S. pharaonis attains two beaks in March-June Onsoy and 
Salman (2005) observed that the spawning period of $S$. officinalis covers the whole year with two maximum peaks in March and June. Ghazvineh et al., 2012 attains two peaks for S. Pharaonis in May and June Persian Gulf in Iran and Dursun et al.,( 2013 )found that the mean monthly female GSIs showed two annual peaks, in spring (May) in addition in autumn (November) for pink cuttlefish Sepia orbignyana in the Aegean Sea. Our results did not conform to Akyol et al., (2011) recorded one beak of Sepia officinalis and varied in spawning seasons. And, Riad. R. et al., (2015) found that the mean monthly of GSI demonstrated one annual peak, early Spring and in Summer, and sometimes extended to Autumn (with one peak) of Sepia pharaonis in the Gulf of Suez. This difference is may be due to environmental conditions (temperature, salinity, PH, organic matter, etc.).

\begin{tabular}{ll} 
Macroscopic maturity stages of Sepia savignyi in the \\
$\begin{array}{c}\text { Maturity } \\
\text { stage }\end{array}$ \\
\hline $\begin{array}{c}\text { Stage I } \\
\text { (Immature) }\end{array}$ & $\begin{array}{l}\text { Ovary very small, disc shape and } \\
\text { occupying the posterior mantle as a } \\
\text { whitish patch in cuttlefish. Nidamental } \\
\text { glands appear as very fine transparent }\end{array}$ \\
& $\begin{array}{l}\text { strip, small in size, accessory nidamental } \\
\text { gland not apparent. }\end{array}$
\end{tabular}

Stage II Ovary occupies nearly half of the (Maturing) posterior body cavity. Individual ova visible. Ovary with uniform sized maturing yellowish oocytes. This stage is very brief. Nidamental glands larger, thicker, pearl-shaped and creamy white, while the accessory nidamental gland was big and orange

Stage III Ovary very prominent with plenty of (Mature) translucent eggs and occupies an entire posterior mantle cavity. Nidamental glands large, thick and creamy white. Accessory nidamental glands were orange in color. Smooth, transparent, mature eggs, the distal part of the ovary with striated eggs and small eggs.

Stage IV The gonad decrease in volume. Ovary (Spawning with few striated loose eggs and few stage) medium to small eggs attached to the connective tissue of the ovary, nidamental glands flabby, accessory nidamental glands orange

Stage V Gonad was gelatinous materials, free of (Spent stage) eggs and yellowish in color. Nidamental glands were flaccid.

Macroscopic maturity stages
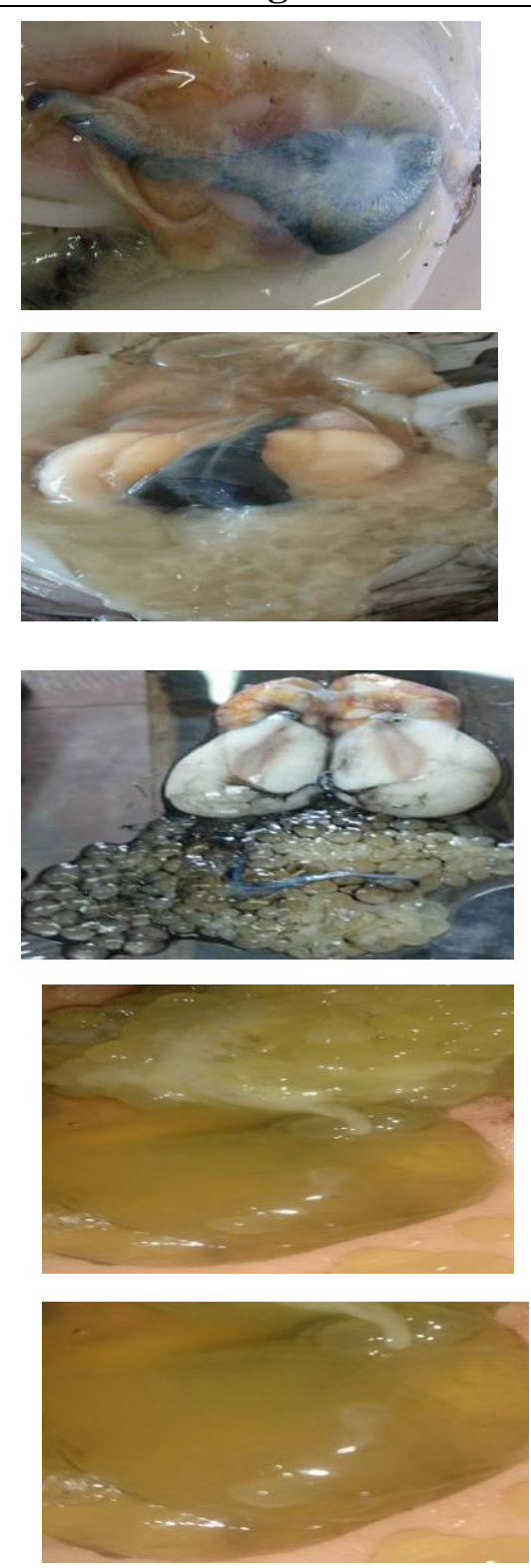


\begin{tabular}{|c|c|c|}
\hline $\begin{array}{l}\text { Maturity } \\
\text { stage }\end{array}$ & Male & Macroscopic maturity stages \\
\hline $\begin{array}{c}\text { Stage I } \\
\text { (Immature) }\end{array}$ & $\begin{array}{l}\text { The testis was thin, flat and the } \\
\text { Spermatophoric sac not visible }\end{array}$ & \\
\hline $\begin{array}{l}\text { Stage II } \\
\text { (Maturing) }\end{array}$ & $\begin{array}{l}\text { The testis was larger than the } \\
\text { previous stage and thicker. The } \\
\text { spermatophoric sac was visible } \\
\text { and empty }\end{array}$ & \\
\hline $\begin{array}{l}\text { Stage III } \\
\text { (Mature) }\end{array}$ & $\begin{array}{l}\text { Creamy white testis large and } \\
\text { fully developed and the } \\
\text { spermatophores packed in a } \\
\text { spermatophoric sac. }\end{array}$ & \\
\hline $\begin{array}{l}\text { Stage IV } \\
\text { (Spawning } \\
\text { stage) }\end{array}$ & $\begin{array}{l}\text { Spermatophoric sac swollen and } \\
\text { full of spermatozoa }\end{array}$ & \\
\hline $\begin{array}{c}\text { Stage V } \\
\text { (Spent stage) }\end{array}$ & $\begin{array}{l}\text { Testis was small, flaccid and } \\
\text { empty of spermatozoa }\end{array}$ & \\
\hline
\end{tabular}

\section{Monthly Distribution of Maturity Stages}

Concerning female $S$. savignyi the happening of spawning stage was observed in September, December, January, February, March, April and May with a high percentage in December(48.2 \%) and April (44\%). The spent stage was recorded a high value in January, (35.7 \%,) and May (31\%).

In the male, $S$. savignyi., the occurrence of spawning stage was seen in November, December, January, February, March, April and May with a high percentage in December (33.8\%) and in April (37.5\%). The spent stage was founded in January, February and May were highest percentages in May (33.4 \%), (Fig. 3). By studying both the percentage distributions of gonadal maturation stages and the monthly variations of the GSI, we suggest an extended spawning period for Sepia savignyi population in the Gulf of Suez. This is similar to the previous described for other cuttlefish species in different areas. Our result agrees with (Gabr et al., 1998; Önsoy and Salman., 2005; Ghazvineh et al., 2012 and Dursun et al., 2013) recorded prolonged spawning season. 

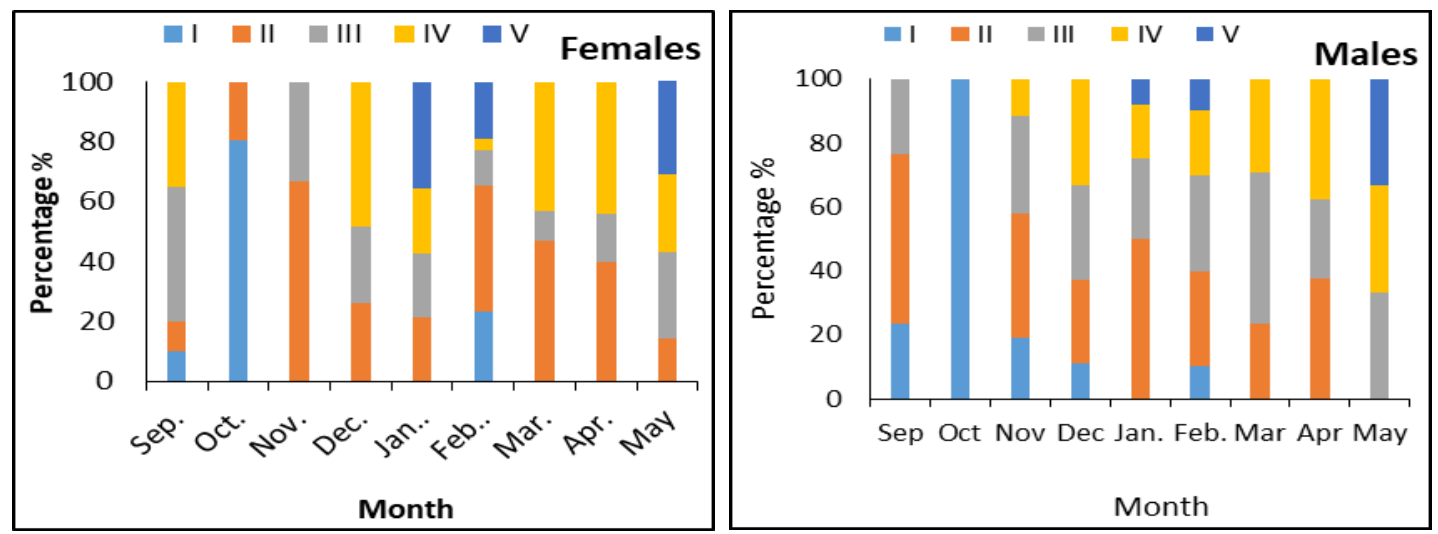

Fig. 3: Monthly percentage change in the female and male gonadal stages of S. savignyi collected from the Gulf of Suez during the fishing season from September 2014 to May 2015

The microscopic character of Sepia savignyi Oogenesis of female, oocyte stages.

There are seven stages of oocyte maturation based on cell types and their proportions, the thickness of the follicular layers of the oocytes follicle invaginations.

\begin{tabular}{cl}
$\begin{array}{c}\text { stages of } \\
\text { oocyte } \\
\text { maturation }\end{array}$ & $\begin{array}{c}\text { The microscopic character } \\
\text { of Sepia savignyi oocyte } \\
\text { stages }\end{array}$ \\
\hline $\begin{array}{c}\text { Stage 1 } \\
\text { Oogonia (OO) }\end{array}$ & $\begin{array}{l}\text { Oogonia are small round cells, } \\
\text { with visible cytoplasm. These } \\
\text { cells are embedded in the } \\
\text { gelatinous material. The } \\
\text { nucleus in the center of the } \\
\text { cell. It's diameter of oocytes } \\
\text { about } 2 \text { mm in average }\end{array}$ \\
$\begin{array}{l}\text { Oocytes are associated with } \\
\text { Primary } 2 \text { Early }\end{array}$ & $\begin{array}{l}\text { one or several follicles. They } \\
\text { have a round shape nucleus, } \\
\text { which migrates to animal pole. }\end{array}$ \\
At this stage diameter of \\
oocytes about 4mm on \\
average.
\end{tabular}


Stage $4-\quad$ The follicle epithelium initiates

Previtellogenic the oocyte embedding by Oocyte (PVO intensive multiplication of the follicle cells (two layers of follicular cells, the inner one consisting of cuboidal cells, the outer one of flat follicular cells), with a subsequent displacement of the nucleus at the polar zone of the cell. In a few oocytes, the follicle cells form a syncytium (folds). These folds can penetrate deep inside the cell and encroach the cytoplasm. Oocyte size increases ( $7 \mathrm{~mm}$ to $8 \mathrm{~mm})$. There is an initiation of nucleoli degeneration and the first production of yolk globules.

Stage 5 -

Vitellogenic Oocyte (VO):

Stage $6-$ Advanced Vitellogenic Oocyte (AVO)

This stage is characterized by a very strong oocyte diameters increase. The follicular epithelium is active in vitellogenesis. The follicular folds are displaced towards the periphery of the oocytes by the formation of the yolk. Oocyte sizes range from $9 \mathrm{~mm}$ to $1.2 \mathrm{~cm}$. In some oocytes, the nuclei in the polar zone are still visible.

These oocytes reach the maximum size $(1.5 \mathrm{~cm})$. The cytoplasm is filled with yolk granules; the folds are beginning reabsorbed towards to the cell wall.

Stage 7 -Ripe Oocytes are issued by the Oocytes (RO): cytoplasm is filled with yolk granules and the folds are completely reabsorbed, involved and protected by the chorion. At the end, they have a distal chorionic a cellular long filament peduncle. These oocytes are ready for ovulation. Oocytes ranged in size from $1 \mathrm{~cm}$ to $1.5 \mathrm{~cm}$
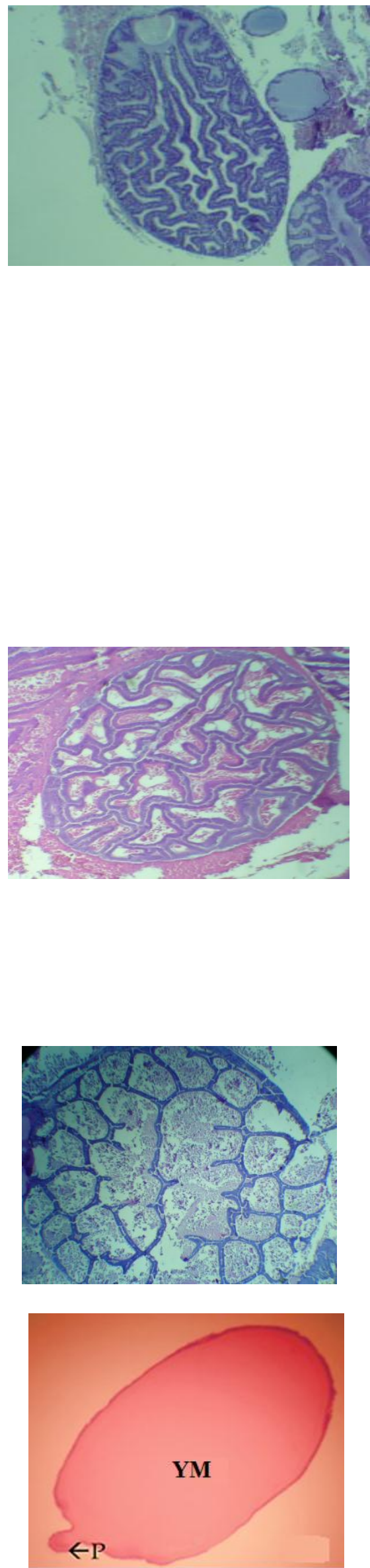
Spermatogenesis of male Spermatogenesis takes place within the seminiferous tubules, the functional units of the testis. From the periphery to the center of each seminiferous tubule in the mature testis can be found spermatogonia, spermatocytes, spermatids, and spermatozoa, respectively (Fig. a).

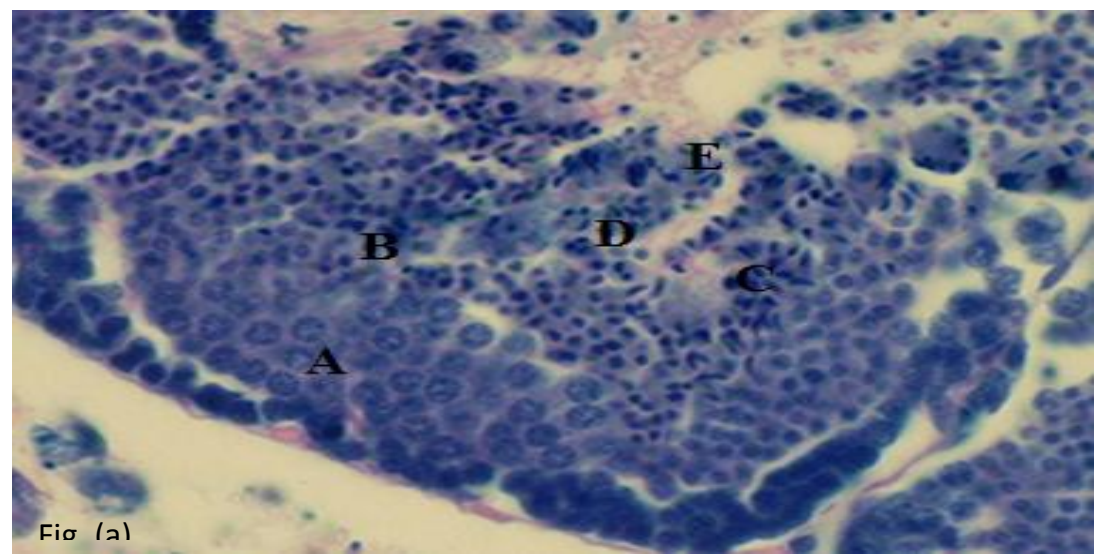

Fig. (a) Microscopic male Sepia savignyi at different maturity stages: Transverse section of Sepia savignyi testis. $\mathrm{A}=$ spermatogonia $\mathrm{B}=$ primary spermatocyte, $\mathrm{C}=$ secondary spermatocyte, $\mathrm{D}=$ spermatid and $\mathrm{E}=$ spermatozoa. $(4 \mathrm{X})$.

Microscopic maturity stages of Sepia savignyi (Females and Males) in the Gulf of Suez as follows:

\begin{tabular}{|c|c|c|}
\hline $\begin{array}{c}\text { Maturity } \\
\text { stage }\end{array}$ & Female & Male \\
\hline $\begin{array}{c}\text { Stage I } \\
\text { (Immature) }\end{array}$ & $\begin{array}{l}\text { Oocytes of young female Sepia savignyi } \\
\text { compactly filled the ovaries. Several } \\
\text { growing showed spherical nucleus by } \\
\text { developing a layer follicle cells. Oocytes } \\
\text { were partially or entirely surrounded by a } \\
\text { single layer of follicle cell. (Plate B: Fig. 1) }\end{array}$ & $\begin{array}{l}\text { Seminiferous tubules are well } \\
\text { defined, but small and empty. Only } \\
\text { spermatogonia are present in low } \\
\text { numbers (Plate C: Fig. b). }\end{array}$ \\
\hline $\begin{array}{c}\text { Stage II } \\
\text { (Maturing) }\end{array}$ & $\begin{array}{l}\text { At this stage, the oocyte began to develop, } \\
\text { showing the continuous growing layer of } \\
\text { follicular cells, and the follicle cell of } \\
\text { oocytes are folded and most penetrate into } \\
\text { the oocytes to form a syncytium (Plate B: } \\
\text { Fig. 2.). }\end{array}$ & $\begin{array}{l}\text { Seminiferous tubules are clearly } \\
\text { defined along the testes. } \\
\text { Spermatogonia, primary and } \\
\text { secondary spermatocytes and } \\
\text { spermatids are present. Spermatozoa } \\
\text { are more evident and visible in all } \\
\text { seminiferous tubules (Plate C: Fig. c). }\end{array}$ \\
\hline $\begin{array}{l}\text { Stage III } \\
\text { (Mature) }\end{array}$ & $\begin{array}{l}\text { In this stage, the majority of oocytes are } \\
\text { transparent beside other oocytes of different } \\
\text { vitellogenin stages. The follicular syncytium } \\
\text { degenerate completely and mature eggs are } \\
\text { ready for the ovulation } \\
\text { (Plate B: Fig. 3). }\end{array}$ & $\begin{array}{l}\text { Seminiferous tubules are large and } \\
\text { well defined. There are no empty } \\
\text { spaces between cells. All types of } \\
\text { cells are present with abundant } \\
\text { spermatozoa in the central lumen } \\
\text { (Plate C: Fig. d). }\end{array}$ \\
\hline $\begin{array}{l}\text { Stage IV } \\
\text { (Spawning } \\
\text { stage) }\end{array}$ & $\begin{array}{l}\text { The most oocytes of this stage in } \\
\text { vitellogenic stage and few oocytes in } \\
\text { previtellogenic stages besides ripe stages in } \\
\text { a few numbers. (Plate B: Fig. 4). }\end{array}$ & $\begin{array}{l}\text { Only a few primary and secondary } \\
\text { spermatocytes, sperm-atids and } \\
\text { spermatozoa are present, dispersed } \\
\text { throughout the seminiferous tubules } \\
\text { (Plate C: Fig. e). }\end{array}$ \\
\hline $\begin{array}{c}\text { Stage V } \\
\text { (Spent stage) }\end{array}$ & $\begin{array}{l}\text { In this stage, gelatinous material is } \\
\text { completely free from oocytes (Plate B: Fig. } \\
\text { 5) }\end{array}$ & $\begin{array}{l}\text { The lobule is empty of spermatozoa, } \\
\text { some of the spermatogonia and } \\
\text { seminiferous tubules are flaccid and } \\
\text { empty of sperms (Plate C: Fig. f). }\end{array}$ \\
\hline
\end{tabular}


Spermatogonia:- These are the largest male cells and they occur in a crypt. They resemble oogonia, but they do not develop a chromatin nucleus. The lack of clear, distinctive morphological features between oogonia and spermatogonia is well known (Plate C: Fig. b).

Spermatocytes:--Primary spermatocyte stage: -This stage characterized by a large nucleus and has a small amount of cytoplasm (Plate C: Fig. c).

-Secondary spermatocyte stage: - This stage demonstrated cells where nuclei well separated and stain darkly (Plate C: Fig. d).

Spermatid stage: - They have small nuclei, are close together, occur in crypts, and they stain dark red (with Hematoxylin and eosin stain) (Plate C: Fig. e).

Spermatozoa: -Spermatozoa are spermatids with tails, which stain blue (hematoxylin); the tails stain pink (eosin) though these can be difficult to see. Spermatozoa in sexually mature males occur in crypts (Plate C: Fig. f).
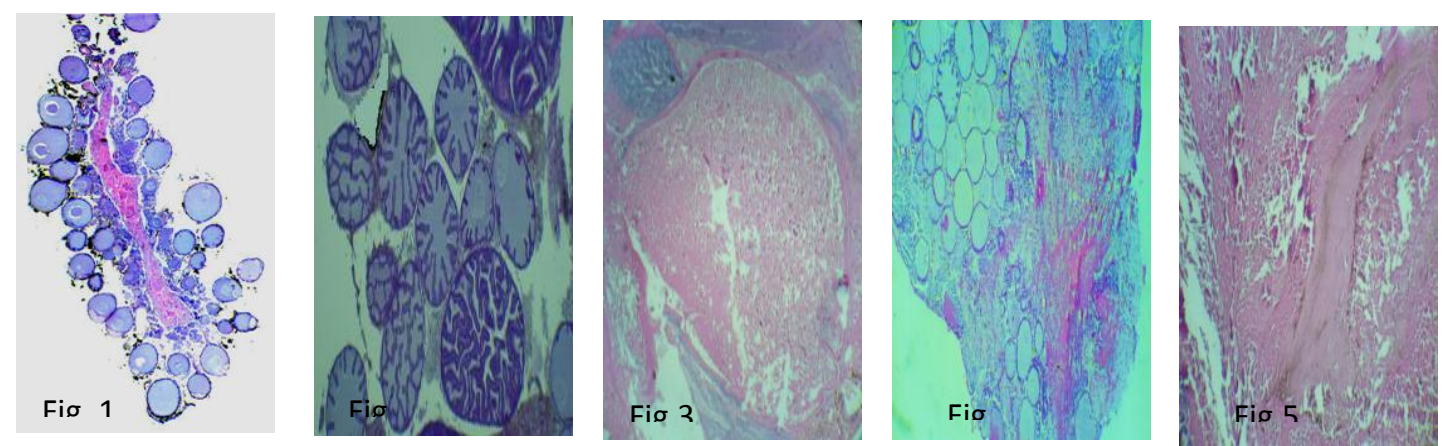

Plate B: Microscopic female Sepia savignyi at different maturity stages. From left to right respectively, Cross section of ovary showing Fig (1) Immature stage (4 X). Fig (2) Maturing stag (4 X). Fig (3) Mature stage (4X), Fig (4) Spawning stage (4X), and Cross section of ovary showing Fig (5) Spent stage (4X) stained with Hematoxylin and Eosin.
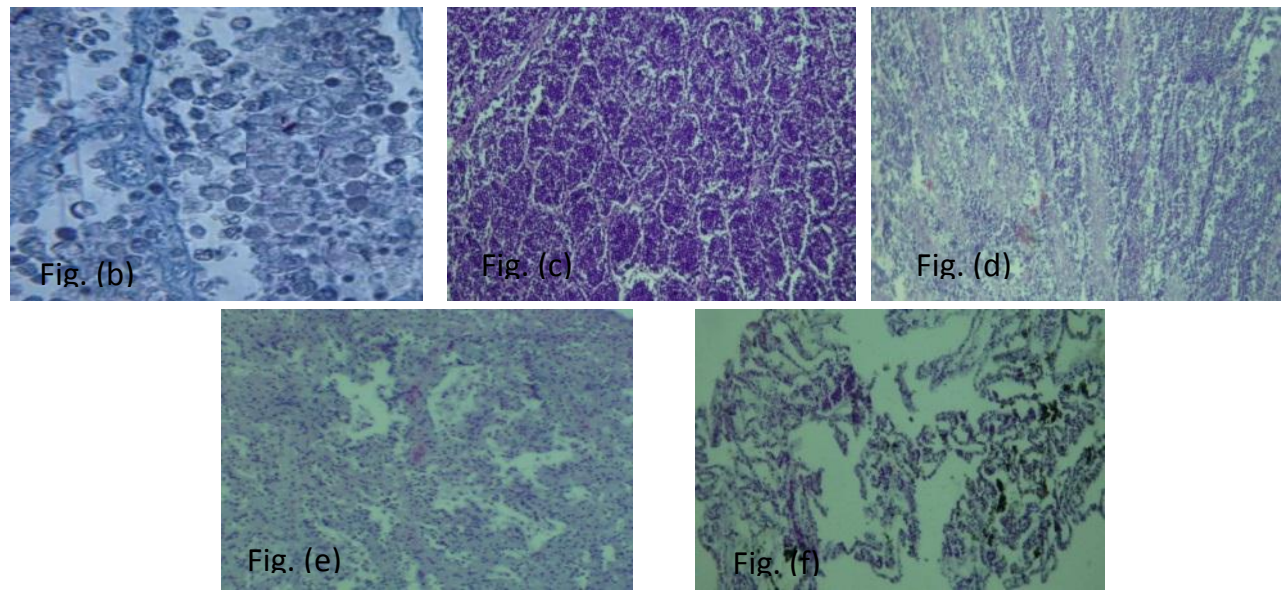

Plate C: Figures (b) (c) (d) (e) and (f) showing Cross section of testis immature stage (4 X). , maturing stage $(\mathbf{4 X})$, mature stage $(\mathbf{4 X})$, spawning stage $(\mathbf{4 X})$.and Spent stage $(\mathbf{4 X})$ respectively stained with Hematoxylin and Eosin

Virtually macroscopic and microscopic studies of cephalopods are shown in Loligo species. Gabr et al,.(1998) the only author which examined the histology of gonad maturity stages of two species $S$. dollfusi and $S$. pharaonis without represented oogenesis and spermatogenesis for ovary and testis, respectively.

The gonad maturation of $S$. savignyi is relatively similar to $S$. pharaonis and $S$. dollfusi Gabr et al., (1998) and Sepia elegans Salman (2015). (Gonçalves et al., 2002; 
Cuccu et al., 2013; and Sieiro et al., 2014), proposed histological approaches for the verification of the macroscopic maturity stages in several cephalopods species. It was possible to observe the nucleolus of $S$. savignyi until the initiation of the development of the first yolk granules. Our studies also, reported that sizes of oocytes, the morphology of nucleus, and the relationship between oocytes and the follicle cells play a role in oocyte development these have been used to define of oocyte development. It is the first study which illustrates the seven stages (1. Oogonia, 2.Early primary oocyte, 3.Late primary oocyte, 4.Previtellogenic Oocyte, 5.Vitellogenic Oocyte, 6.Advanced Vitellogenic Oocyte, 7.Ripe oocyte)of oocyte oogenesis development in female $S$. savignyi.

In an early stage the oocytes are surrounded by a simple layer of follicle cells, then the formation of the follicle cells of a syncytium, followed by vitellogenesis. Finally, the follicular syncytium degenerates and the mature eggs are ready for the ovulation Arnold and Williams-Arnold (1977). In this study, the gonadal development of female $S$. savignyi was divided into five maturity stages as stage I immature, stage II (maturing), stage III (mature), stage IV (spawning), and V (spent), which defined by observations of the oocytes that appear in its ovary.

The individuation of ripe oocytes bearing a peduncle, not obvious to the naked eye. It is known that the peduncle is necessary during spawning when the eggs are interwoven to form the strings Mangold (1983) that attach to the shelters by means of secretions Frösch and Marthy (1975). The ovaries of spent specimens (stage V) contained post ovulatory follicles. Overall, the scales proposed in this research allow easy identification of different phases of sexual maturation for S. savignyi and can be an important tool to define evaluation models for sound management of the species. The present work provides the first reported on the microscopic of spermatogenesis of the Sepia savignyi exhibiting the details of the morphological characteristics, the pattern of lobules in the spermatogonia, spermatocytes, spermatids, and spermatozoa stage. There has not been any record of details of spermatogenesis in the cuttlefish. However, many studies on spermatogenesis in other species of cephalopod family groups are available such as Loligo sp. Laptikhovsky and Arkhipki (2001) and Squid species. Sirinupong (2012).

Histologically, the testis of $S$. savignyi has a tubular structure, as it is certainly observed that the spermatogonia are associated with the tubular basement membrane and different maturation stages of spermatocytes are sorted into the lumen, so it is possible to detect all maturation stages in any section of the tubule. Several authors consent with this description in several cephalopods Budelmann et al., (1997) and Olivares-Paz et al., (2001)

The labeling of the stages of gonadal development in male $S$. savignyi is five stages which differ than Gabr et al. (1998) who observed four stages of the gonadal development in the cuttlefish of Sepia pharaonis and S. dollfusi.

- In mature males, the spermatozoa are full the lobules with represented spermatocytes and spermatids as other cephalopods in Mediterranean areas Guerra, (1988), comparable to that found by Silva et al. (2002) in the Gulf of Cádiz and Otero et al. (2007) for the Galician waters. The flaccid appearance of the testis in the spent specimens corresponds to the large spaces inside the tubules as a result of the small number of germinal cells Cuccu et al., 2013).

This paper deals a detailed description of the macroscopic and microscopic structure of gonad $S$. savignyi. In addition, we suggest a simple microscopic scale that 
can be utilized to estimate the maturity degree of the gonads, which can be used in the following research.

\section{REFERENCES}

Akyol, O.; Tellibayraktar, B. and Ceyhan, T. (2011). Preliminary results on the cuttlefish, Sepia officinalis, reproduction in Izmir Bay (Aegean Sea). Journal of Fisheries Sciences, 5(2): 122-130

Arnold, J. M. and Williams-Arnold, L. D. (1977). Cephalopoda, Decapoda. In: Reproduction of marine invertebrates, Molluscs: Gastropods and Cephalopods, Vol. 4.A. G. Giese and J. S. Pears (eds.).Academic Press, p. 243 - 290.

Bancroft, J.D. and Stevens, A. (1996).The hematoxylin and eosin. Theory and practice of histological techniques. 4th ed, Ch 6, pp.99-112.

Boletzky, S.V. (1988). A new record of long-continued spawning in Sepia officinalis (Mollusca, Cephalopoda). Rapp Comm Int Mer Médit, 31(2), p.257.

Budelmann, B.U.; Schipp, R. and Von Boletzky, S. (1997). Cephalopoda In: Microscopic anatomy of invertebrates. Harrison FW, Kohn AJ, eds. Vol. 6A. New York, WileyLiss, 1997. P.119-414.

Cuccu, D.; Mereu, M.; Cau, Al., Pesci, P. and Cau, A. (2013). Reproductive development versus estimated age and size in a wild Mediterranean population of Octopus vulgaris (Cephalopoda: Octopodidae). Journal of the Marine Biological Association of the United Kingdom, 93(3): 843-849.

Dursun, D.; Eronat, E.G.T.; Akalin, M. and Salman, M.A (2013). Reproductive biology of pink cuttlefish Sepia orbignyana in the Aegean Sea (eastern Mediterranean). Turkish Journal of Zoology, 37(5): 576-581.

El- Sherbeny, A. S. (2009). Study Population Dynamics and Fisheries Management of Cuttlefish in the Gulf of Suez, Red Sea (M. Sc.) Faculty of Science, Suez Canal University

Frösch, D. and Marthy, H.J. (1975).The structure and function of the oviducal gland in octopods (Cephalopoda). Proceedings of the Royal Society of London, Series B, 188: 95-107.

Gabr, H.R.; Hanlon, R.T.; Hanafy, M.H. and El-Etreby, S.G.(1998). Maturation, fecundity and seasonality of reproduction of two commercially valuable cuttlefish, Sepia pharaonis and $S$. dollfusi, in the Suez Canal. Fisheries research, 36(2-3): 99-115.

Ghazvineh, L.; Valinassab, T.; Savari, A. and Ghobadiyan, F. (2012). Reproductive Biology of the Pharaoh Cuttle Sepia pharaonis in the Persian Gulf. World Journal of Fish and Marine Sciences, 4(3): 313-319.

Gonçalves, I.; Sendão, J. and Borges, T.C. (2002). Octopus vulgaris (Cephalopoda: Octopodidae) Gametogenesis: a Histological Approach to the Verification of the Macroscopic Maturity Scales. Abhandlungen der Geologischen Bundesanstalt, 57: 7988.

Guerra, A. and Castro, B.G. (1988). On the life of Sepia officinalis (Cephalopoda, Sepioidea) in the Ria de Vigo (NW Spain). Cahiers de biologie marine, (3).

King, M. (1995). Fisheries biology, Assessment and management. Fishing news books. Australia, 341pp.

Laptikhovsky, V.V. and Arkhipkin, A. I. (2001). Oogenesis and gonad development in the cold water loliginid squid Loligo gahi (Cephalopoda: Myopsida) on the Falkland shelf. Journal of Molluscan Studies, 67(4): 475-482.

Mehanna, S.F. and El-Gammal, F.I. (2010). Growth and population dynamics of the cuttlefish Sepia savignyi Blainville in the Gulf of Suez, Red Sea. Indian J. Fish, 57(1): $1-6$.

Mangold, K. (1983). Octopus vulgaris. Cephalopod life cycles, 1, pp.335-364.

Paz, A.O.; Covarrubias, M.Z.; Reyes, P.P. and Romero, O.Z. (2001). Estudio Histológico de la ovogénesis y maduración ovárica en octopus mimus (Cephalopoda: Octopodidae) de 
la ii región de chile histological study of oogenesis and ovaric maturation in octopus mimus (Cephalopoda: Octopodidae) from the coast of the ii region, chile. Estud. Oceanol, 20: 13-22.

Önsoy, B. and Salman, A. (2005). Reproductive biology of the common cuttlefish Sepia officinalis L. (Sepiida: Cephalopoda) in the Aegean Sea. Turkish Journal of Veterinary and Animal Sciences, 29(3): 613-619.

Otero, J.; González, Á.F.; Sieiro, M.P. and Guerra, Á. (2007). Reproductive cycle and energy allocation of Octopus vulgaris in Galician waters, NE Atlantic. Fisheries Research, 85(1-2): 122-129.

Riad, R.; Atta, M.; Halim, Y. and Elebiary, N.(2015). Reproductive biology of Sepia Pharaonis Ehrenberg, 1831 (cephalopoda sepioidea) from the Suez Gulf (Red Sea), Egypt .Journal of. Aquatic. Biology and Fisheries, 19(4):91-102

Salman, A. (2015). Reproductive biology of the elegant cuttlefish (Sepia elegans) in the Eastern Mediterranean. Turkish Journal of Fisheries and Aquatic Sciences, 15(2), pp.265-272.

Sieiro, P.; Otero, J. and Guerra, Á. (2014). Contrasting macroscopic maturity staging with histological characteristics of the gonads in female Octopus vulgaris. Hydrobiologia, 730(1): 113-125.

Silva, L.; Sobrino, I. and Ramos, F. (2002). Reproductive biology of the common octopus, Octopus vulgaris Cuvier, 1797 (Cephalopoda: Octopodidae) in the Gulf of Cádiz (SW Spain). Bulletin of Marine Science, 71(2): 837-850.

Sirinupong, P. (2012).Reproductive biology and distribution of Neuropeptide APGW amide in the brain and reproductive organs of pygmy squid Idiosepius pygmaeus (Steenstrup, 1884) Ph.D.

\section{ARABIC SUMMARY}

\section{بعض النواحي البيولوجية والهستولوجيه لمناسل سيبيا سافينىSepia savignyi (Blainville, 1827 في خليج السويس , مصر.

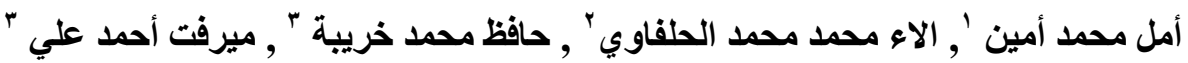

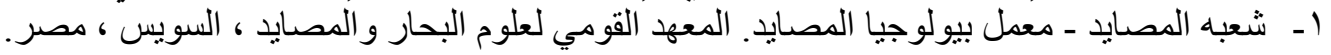

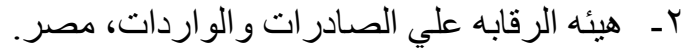 rـ ـ قسم الإنتاج الحيو اني والثروة السمكية ـ كلية الزر اعة ـ جامعة قناة السويس ـ مصر.}

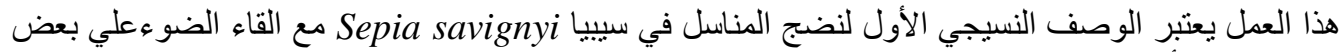

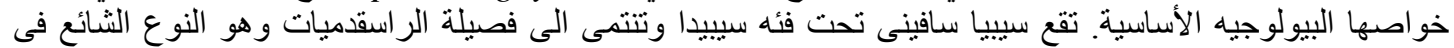

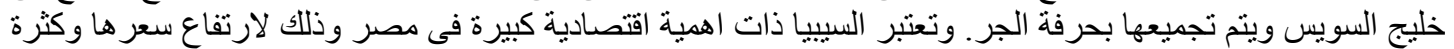

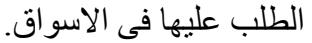

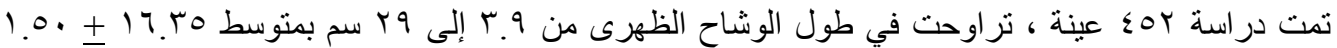

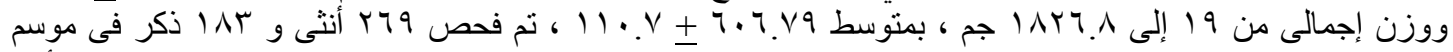

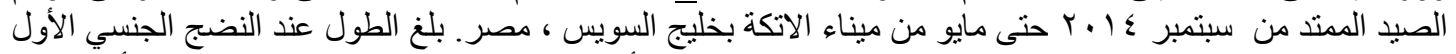
(الإن

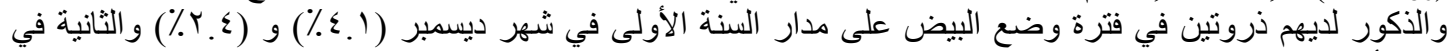

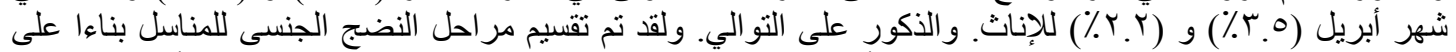

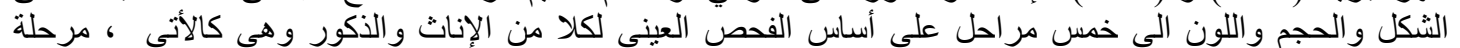

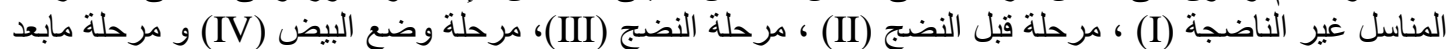

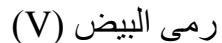

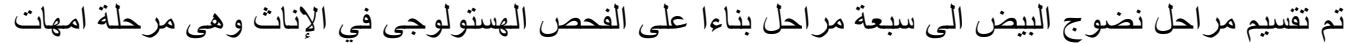

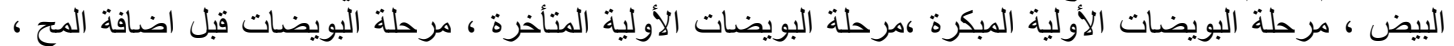

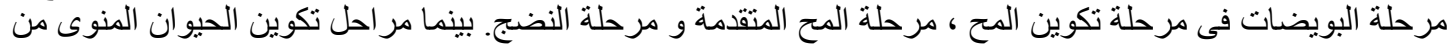

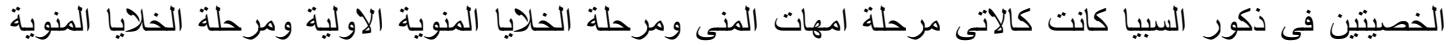
الثانوية ومرحلة الطلائع المنوية ومرحلة الحيوانات المنوية. 